\title{
Exchange Rate Management and the Manufacturing Sector Performance in the Nigerian Economy
}

\author{
Dr. Christopher Ehinomen ${ }^{1}$, Mr. Tomilade Ibrahim Oladipo ${ }^{2}$ \\ ${ }^{I}$ Department of Economics and Business Studies, College Of Management Sciences, \\ ${ }^{2}$ Redeemers University, K/M 46/85 Lagos/Ibadan Expressway, Redemption City, Mowe, Ogun State, Nigeria
}

\begin{abstract}
Since Nigeria is heavily factor-input import dependent, the inability to locally source the required inputs in the manufacturing sector in the country is a chronic problem. Consequently, the exchange rate plays an important role in the ability of the economy to attain a realistic growth in the manufacturing sector. This study examined the impact of exchange rate management on the growth of the manufacturing sector in Nigeria. Ordinary Least Square (OLS) multiple regression analysis, using E-view was employed. The study covered the periods of 1986-2010 with the use of time-series data. The empirical result of this study shows that depreciation which forms part of the structural adjustment policy (SAP) 1986, and which dominated the period under review has no significant relationship with the manufacturing's sector productivity. It was found that in Nigeria, exchange rate appreciation has a significant relationship with domestic output. And that exchange rate appreciation will promote growth in the manufacturing sector. It was also ascertained from the estimated regression line that there is a positive relationship between the manufacturing gross domestic product and inflation. It is recommended that government should direct its exchange rate management policy towards exchange rate appreciation in order to reduce the cost of production in the manufacturing sector that depends heavily on foreign inputs while there should be total ban of importation on consumer and intermediate goods that can be produced locally. Since manufacturing sector depends much on foreign inputs, and for the importation of these foreign inputs not be continuous, efforts should be geared towards improving the level of technology, increasing agricultural production, and developing local raw materials in the country. In addition, the government should ensure stable electricity, good roads, water, telecommunication etc. And more importantly as regards this study, the exchange rate appreciation is what the Government should intensify efforts to achieve in Nigeria.
\end{abstract}

\section{Introduction}

The Central Bank of Nigeria (CBN) [1] in its annual reports (various editions) highlighted that during the 1960s and early 1970s, manufacturing activities were positively accelerated and value added per worker was at par with, if not higher than that in other African countries such as Botswana, Ghana and Kenya. During this period the share of manufacturing in GDP nearly doubled from less than 5 percent to 8 percent and on that trend many people believed that the country was on a path to industrialization. It was observed, however, that as from the 1980s manufacturing firms in Nigeria experienced relative stagnation as the sectors value added per capital lagged behind that of many comparator countries. Presently, the manufacturing sector is experiencing collapse with an average capacity utilization hovering around 40 percent. The Manufacturers Association of Nigeria (MAN) [2] in a survey carried out as part of its membership operational audit in January 2010, recorded that of the 2780 registered members, a total of 839 (30.2\%) manufacturing firms closed their factories in 2009. This is due to their inability to cope with the challenges posted by the harsh operating environment in Nigeria; which include the exchange rate management problems and infrastructural decay. In the annual report of MAN for 2006, it was also claimed that the job loss in the sector between 1983 and January 2006 was estimated at 4.2 million. In addition, in the Newsletter edition of the Association for March, 2010, it was reported that one million jobs have been lost in the sector between 2006 and 2010.

Ubok-Udom, E. (1999) in his work titled currency depreciation and domestic output growth in Nigeria, [3], found that development strategy was import dependent; thus leading to foreign exchange problems. Thus, the ineffectiveness in the management of the exchange rate has contributed greatly to the low capacity utilization in the manufacturing sector in Nigeria. Hence, this study sets out to access the extent of correlation between the exchange rate management and performance in the manufacturing sector in Nigeria. The structure of this paper is as follows: section II focuses on the status of manufacturing sector, as well as exchange rate policies in Nigeria. Section III deals on the theoretical framework and reviews relevant literature for the study. Section IV contains the model specification and empirical results of the study. In section $\mathrm{V}$ the paper concludes with summary and policy implications of the study. 


\section{Background}

\subsection{Status of Manufacturing Sector in Nigeria}

In the 1960s and 1970s Nigeria was said to be on a path to industrialization (Central Bank of Nigeria (CBN) in its annual reports -various editions-). It was observed however that as from the 1980s manufacturing firms in Nigeria experienced relative stagnation as the sectors value added per capital lagged behind that of many comparable countries.

- Presently, the manufacturing sector is experiencing collapse with an average capacity utilization hovering around 40 percent.

- The Manufacturers Association of Nigeria (MAN) in a survey carried out as part of its membership operational audit in January 2010, recorded that of the 2780 registered members, a total of 839 manufacturing firms closed their factories in 2009. This is due to their inability to cope with the challenges posted by the harsh operating environment in Nigeria. The table below shows the number of manufacturing firms that shut down their operations across the country.

Table I: Manufacturing Companies in Nigeria that shutdown in 2009

\begin{tabular}{|l|l|l|}
\hline Manufacturing Enclaves & States Involved & Number of firms that shut down \\
\hline Northern Area & Kaduna, Kano & 176 \\
\hline South-East Area & Anambra, Enugu, Imo, Abia & 178 \\
\hline South-South & Rivers, Cross River, Akwa Ibom & 46 \\
\hline South-West & Oyo, Ogun, Osun, Ekiti, Kogi, Kwara & 225 \\
\hline Lagos Area & Ikeja, Apapa, Ikorodu & 219 \\
\hline
\end{tabular}

Source: The Manufacturing Association of Nigeria Membership Operational Audit Survey 2009.

As shown in table 1 the implication of the large number of closed manufacturing firms is that it has worsened the country's growing unemployment rate which leads to poverty as a result of loss of wage employment. From table 1, the South-West geo-political region was the most affected of the shut-down of operations with 225 firms unable to operate since 2009.

Table II shows the sectoral group of MAN. Presently, the manufacturing sector is divided along the following sectoral group.

Table II: Sectoral Group of Manufacturing firms in Nigeria.

\begin{tabular}{|l|l|}
\hline S/N & Sector Group \\
\hline 1. & Food, Beverages and Tobacco \\
\hline 2. & Chemical and Pharmaceutical \\
\hline 3. & Domestic and Industrial Plastic \\
\hline 4. & Rubber and Foam \\
\hline 5. & Basic Meal \\
\hline 6. & Iron Steel and Fabricated Metal Products \\
\hline 7. & Pulp, Paper and Paper products \\
\hline 8. & Printing, Publishing and Packaging \\
\hline 9. & Electrical and Electronics \\
\hline 10. & Textile, Weaving Apparels \\
\hline 11. & Carpet, Leather/Leather Footwear \\
\hline 12. & Wood and Wood Products including Furniture \\
\hline 13. & Non-Metallic Mineral Products \\
\hline 14. & Motor Vehicle and Miscellaneous Assembly \\
\hline 15. & MAN Export Group \\
\hline
\end{tabular}

Source: Manufacturers Association of Nigeria Sectoral Group.

Annual Report 2009: Available at www.manufacturersnigeria.org

$>$ In the annual report of MAN for 2006, it was also claimed that the job loss in the sector between 1983 and January 2006 was estimated at 4.2 million. In addition, in the Newsletter edition of the Association for March, 2010, it was reported that one million jobs have been lost in the sector between 2006 and 2010.

$>$ Various factors have been advanced for the collapsing situation of the manufacturing sector. MAN (2006) identified the problems confronting the sector among others to include:

- Poor power (Electricity) supply

- Dilapidated infrastructure

- Lack of access to corporate finance 
- Policy inconsistency

- Multiple taxation

- Corruption

- Lack of adequate take off incentives for new business and

- General poverty in the land which places serious strain or the manufacturing firms.

Ogundele (2000) [4], Malik, Ted and Baptist (2006) [5] in their survey of Nigerian manufacturing firms found that the sector is having problems due to the factors listed below:

- Power shortage 70\%

- Lack of demand for the products $60 \%$

- Lacks of finance/capital $20 \%$

- Lack of imported raw materials $20 \%$

- Lack of domestic raw materials $20 \%$

- Problems of information technology $10 \%$

- Foreign competitors 5\%

- The World Bank (2006) [6] in the report of survey of investment climate in Nigeria, ranked constraints in the manufacturing sector as follows:

- Electricity $80 \%$

- Access to finance $41 \%$

- Transportation $38 \%$

- Multiple Taxes $25 \%$

- Crime $24 \%$

- Corruption $22 \%$

- Others $22 \%$

Malik, Ted and Baptist (2006) also identified the lingering problems of the manufacturing sector to include:

(a) Low investment which has made it difficult for manufacturing enterprises to acquire modern facilities, information technology and human resources development which are critical in reducing production costs, raise productivity and improve competitiveness. Low investments have been traced largely to banks unwillingness to make credit available to the manufacturers as a result of their perception that manufacturing in the Nigerian environment is a risky venture.

(b) Low level of capacity utilization. Generally capacity utilization rate in the manufacturing sector is between 30 and 40 percent indicating gross underutilization of resources due to a number of factors which have been identified and discussed in this paper.

(c) High cost of production traced largely to poor performing infrastructural facilities; and

(d) Inflation.

\subsection{Exchange Rate Policies in Nigeria}

Exchange rate management in Nigeria has undergone various changes since the enactment exchange control act of 1962 but spanning between the two regimes (the fixed and floating exchange rate regimes). The fixed exchange rate was in place before 1986 while the flexible exchange rate regime remains in use from 1986 till date with series of modification.

\subsubsection{Exchange Rate Management in Nigeria Before 1986}

The fixed exchange rate was in vogue between 1962 and 1986. At initial stage, the Nigeria currency was pegged at par with pound sterling, but in 1907, when the British pound was devalued, Nigeria government decided to peg the domestic currency to the dollar at an overvalued rate in other to make imports cheap for the import substituting industries. They relied heavily on foreign inputs and plants and machinery. In December when the USA decided not to desist from converting the dollar into gold, the value of naira was adjusted in relation to the America dollar against a basket of twelve (12) currencies.

Between 1971-1985, Nigeria government witnessed increase revenue and foreign exchange earnings due to earnings from crude-oils, naira was deliberately appreciated and this triggered a number of problems in the external sector, such as rapid erosion of country external reserve. By 1985, the naira was quoted against the US dollar, which became the intervention currency to date.

\subsubsection{Exchange Rate Management After 1986}

The management of exchange rate after 1986 became more market oriented. This started by introducing the second tier foreign exchange rate and foreign exchange allocation for private sector, and was freely determined by forces of demand and supply; while the central bank determines the supplies of the foreign exchange on a weekly basis. 
The introduction of SFEM was followed by depreciation of naira to ensure the efficient allocation of resources. It was envisaged that the depreciation of naira will increase local sourcing of raw materials and bring about growth in manufacturing while discouraging the excessive demand for import as was experienced during the fixed exchange era.

The SFEM which comprises of first tier and second tier exchange rate was merged into a unified foreign exchange market (FEM) on July 2, 1987 with all transaction guided by market forces. An autonomous foreign exchange market which was created in 1988 was highly destabilized due to its speculative tendencies and was subsequently merged with (FEM), when the interbank foreign exchange market (IFEM) segment in which authorized dealers were allowed to transact. Under IFEM, the exchange rate was determined through one or more of the following; marginal rate pricing, in the same year, the bureau de change was introduced to accord increased access to small users of foreign exchange in a less formal manner and encourage the integration of the informal market to the officially recognized market. Inspite of various modifications such as introduction of Dutch Auction System (DAS), December 1990, foreign exchange continues to increase. In 1992, IFEM was depreciated by the adoption of completely regulated exchange rate regime. CBN was unable to meet all the demands of authorized dealers. The authority, however, reverted to a fixed exchange rate regime in 1994 in which naira was pegged at $\mathrm{N} 21.9960: \$ 1$.

This regime worsened the situation in the FEM as naira depreciated sharply and demand for foreign exchange continuous to rise. The authority later returned to the dual exchange rate regime in 1995, a combination of official market and autonomous foreign exchange transaction until it was replaced by a new interbank foreign exchange market (FEM) in October 1999. Later the government re-introduced the Dutch Auction System (DAS) on July 2002 purposely to narrow the gap between the official market and parallel market rates and converse the foreign exchange reserves. Since July 2002, the foreign exchange market became a little restricted by abolishing the interbank transactions, while transactions were made through Dutch Auction System (DAS) which was regarded as a better alternative.

\subsection{Theoretical Framework:}

\section{Theoretical Framework and Review of Empirical Studies.}

Three broad models of exchange rate determination appeared to be more common in the literature. They are mainly: the balance of payment (BOP) model, monetary model and portfolio - balance model It is also worth noting that (i) the Purchasing Power Parity Theory and (ii) the Uncovered Interest Parity have contributed to the development of Monetary and Portfolio Balance.

\subsubsection{The Purchasing Power Parity (PPP) Theory.}

The Purchasing Power Parity (PPP) simply states that a unit of any given currency should be able to buy the same quantity of goods in all countries. Many economists believe that the ppp describes the forces that determine exchange rates in the long run. Accordingly, the nominal exchange rate between the currencies of two countries must reflect the different prices level in those countries. PPP, which forms a strong building block of the theory of exchange rate determination, maintains that there exists a proportional relationship between the exchange rate of the currencies of two countries and their relative inflation rates. The theory is based on the law of one price, which explains that, in the absence of trade barriers and transportation costs, spatial commodity arbitrage ensures that the price of any good is equalized across different countries.

The PPP theory can be formulated in two forms: in absolute forms. The absolute form of PPP asserts that the equilibrium exchange rate equalizes the general purchasing power of a given income in terms of relative price levels. It thus, relates the level of exchange rate to relative prices levels. The relative form argues that changes in exchange rate measured from a base period reflect changes in relative price levels.

\subsubsection{The Uncovered Interest Parity (UIP).}

The Uncovered Interest Parity is the capital account equivalent of the purchasing power parity. This forms the central assumption of the Capital Account Monetary Model of exchange rate determination, which maintains that exchange rate moves in such a way that the expected rates of return are equalized across countries. This implies that the spot rate and expected value of future exchange rate, in asset market equilibrium in such a way that investors are indifferent between the currencies in which they hold assets given the relevant interest rate $\left(r_{d}\right.$ and $\left.r_{f}\right)$.

The UIP assumes that capital is perfectly mobile across countries, that is, there are no exchange controls, no transaction costs, and that investors are risk neutral. This implies that assets denominated in different currencies are regarded by investors as perfect substitutes. Hence, the law of one price will hold for asset returns rather than prices of tradable goods. Under this scenario, if the expected changes in the nominal spot exchange rates reflect that expected inflation rate differential in two countries which ensure that real exchange rate remains constant, UIP implies that the real interest rates will be the sam $3.2 \mathrm{e}$ in two countries. 


\subsubsection{The Balance of Payment (BOP) Model.}

The BOP model explains that exchange rate is determined by the capital flow arising from international trade in goods, services and financial assets in such a manner that the balance of payment equality is maintained at all times. It, thus, uses the balance of payment equality as a condition of equilibrium in the foreign exchange market. A clear exposition and early empirical application of the various versions of this model shows the theory in the following equation:

$\mathrm{BOP}=\mathrm{CU}\left(\mathrm{P}^{*} / \mathrm{P}, \mathrm{Y} . \mathrm{Y}^{*}\right)+\mathrm{CA}\left(\mathrm{r} . \mathrm{r}^{*}, \mathrm{~s}\right)=0$

Where BOP $=$ Balance of Payments

$\mathrm{P} * / \mathrm{P}=$ Relative price of foreign to domestic goods, as a measure of competitiveness

$\mathrm{CU}=$ Current Account

$\mathrm{CA}=$ Rate of capital inflow.

$\mathrm{Y}, \mathrm{R}=$ Income and interest rates respectively

$\mathrm{S}=$ Proxy for speculation.

This equation based on the argument that the current account is influenced by the exchange rate to the extent that it alters relative prices, that is, the degree of competitiveness and the Capital Account is also affected so long the expectation variables play a significant role. From an initial position of balance of payment equilibrium, given prices, foreign income and interest rates. In order to bring back the balance of payment to its initial equilibrium, there is the need for higher interest rate that will generate an offsetting rate of Capital outflow. In the analysis, exchange rate is thus shown to depend more importantly on income, interest rates and relative prices, that is

$\mathrm{ER}=\mathrm{ER}(\mathrm{P} * \mathrm{P}, \mathrm{r}, \mathrm{r}, * \mathrm{Y}, \mathrm{y} *)$

From the model, a rise in income, due to possible autonomous increase in spending, will then require an offsetting depreciation. Increases in both foreign prices and domestic interest rate will lead to an offsetting appreciation. The foregoing explanation brings out two important arguments of the BOP model, which contradict the monetary model. One is that exchange rate changes alter relative prices and competitiveness, and increases in interest rates produces exchange rate appreciation.

\subsection{International Monetary Model.}

The monetary model recognizes the importance of asset market changes in determining the exchange rate, as opposed to concentrating merely on the importance of current account flows in the short or long term, as the previous approaches did. It, thus, emphasizes that exchange rate changes are greatly influenced by the asset holders' preference for money. Its central argument is that adjusted by capital transaction through a change in the exchange rate. This explains that exchange rates changes are brought by stock disequilibrium, that is, the willingness of the individuals to hold the outstanding stock of money, rather than from the flow of receipts and payments arising from this perspective, exchange rate is defined as the price of foreign money in terms of domestic money. Thus, being a relative price of two assets (money), the equilibrium exchange rate is attained when the existing stocks of the two moneys are willingly held. It is reasonable, therefore, that monetary model is based on the assumptions that (i) the demand for money balances is a stable function of real income and interest rates, (ii) that prices are determined by the world price level and the exchange rate through purchasing power parity (PPP) and (iii) that the domestic economy is at full employment level with wage flexibility.

\subsection{Portfolio Balance Approach (PBA.).}

The portfolio - balance model, like the monetary model, is also an asset view of exchange rate determination and stresses the role of asset market adjustment with the assumption of perfect capital mobility. But unlike the monetary model, it assumes substitutability of domestic and foreign interest- bearing assets due to the perceived existence of exchange, political and default risks. It argues those exchange rates reflects the supplies of and demand for a whole range of different currency denominated assets.

\section{Review of Empirical Studies:}

Several studies have examined the relationship between exchange rate and economical aggregates. Most of the attempts have been to relate exchange rate changes or valuation episodes (period of currency depreciation and periods of stability) to aggregate output (growth rate). Ubok-Udom (2004) [7] had it that some peculiar features of the Nigerian economy would lessen the efficacy of currency depreciation in producing desirable effect. Thus, he examined the relationship between exchange rate variations (and currency depreciation) and the growth of domestic output in the Nigerian economy over a 25 year period (1971-1995). He expressed the growth of domestic output (total GDP, non oil GDP and oil GDP) as a linear function of variation on the average nominal exchange rate, while a dummy variable was used to capture the period of currency depreciation and a time trend variable, which is expected to reflect the influence of any time trend on output growth. This equation was estimated using both naira valued output and US dollar valued output respectively. 
The empirical results of the study showed that all the co-efficient of the major explanatory variable (exchange rate variation, dummy variable capturing currency depreciation) has negative signs in all the estimated equations. He interpreted the result by stating that the rate of growth of total GDP and non oil GDP tends to decline or rise with nominal Naira/US dollar exchange rate. Further, the result revealed that the coefficient of the major explanatory variables in the equations estimated with the Naira valued GDP were statistically insignificant, while that of dollar valued were statistically significant at 5\% and $10 \%$ level. He concluded that the result were generally in contrast with the theoretical expectation that currency depreciation promotes domestic output growth and that the exchange rate depreciation opted for since the introduction of SAP in 1986 may have resulted from a wrong policy prescription for Nigerian economy; while apparently required exchange rate appreciation for its growth. He also called for further investigation so as to be sure of the exact relationship between depreciation and GDP growth rate (both oil and non oil GDP). Ogindele (2000) used simultaneous equation to estimate the equation as well as simultaneous to forecast the trend of growth of macroeconomic variables, which covered the period of 2001-2005 (period of alternative trade and exchange rate policies). The results from the simultaneous equation and the reduced form model showed that the exchange rate and trade policy were statistically significant at less than $1 \%$ on its impact on real non oil export growth with a positive relationship. It showed that the annual percentage variation of exchange rate and significance on real non oil export growth. He likened the result to the fact that production activities in Nigeria non oil sector depend heavily on imported input. He stressed further that the theoretical expectation that currency depreciation promotes domestic output were not valued in Nigeria's case. He concluded by using simulation analysis to show that appreciation of currency that promote demand for foreign input has a high tendency to promote domestic production (manufacturing output).

\section{Model Specification and Empirical Results}

The model is in its implicit form is given below:

$\mathrm{MGDP}=\mathrm{f}(\mathrm{EXP}, \mathrm{INF}, \mathrm{DUM}, \mathrm{DUM}, \mathrm{MFDI}, \mathrm{RIR}) \ldots . .(1)$

$\mathrm{MGDP}=\mathrm{b} 0+\mathrm{b} 1 \mathrm{EXR}+\mathrm{b} 2 \mathrm{INF}+\mathrm{b} 3 \mathrm{DUM}+\mathrm{b} 4 \mathrm{DUM}+\mathrm{b} 5 \mathrm{MFDI}+\mathrm{b} 6 \mathrm{RIR}+\mathrm{U} \ldots \ldots$ (2)

Where;

MGDP=Manufacturing's Gross Domestic Product

MFDI= Manufacturing's Direct Investment

$\mathrm{EXR}=$ Exchange rate

$\mathrm{INF}=$ Inflation

RIR= Real Interest Rate

DUM= Dummy variable (which capture the exchange rate depreciation and appreciation)

$\mathrm{U}=$ Stochastic error term

$\mathrm{B} 0=$ Constant intercept

The formula is

Ei-E0/Ei was used for the for exchange rate variation.

Where $\mathrm{Ei}=$ Current nominal exchange rate

Eo $=$ represents previous nominal exchange rate

To examine the relationship between the exchange rate and the productivity of the manufacturing sector, the following hypothesis were tested:

H0: There is no relationship between exchange rate and manufacturing sector productivity

H1: There is relationship between exchange rate (depreciation and appreciation) and manufacturing sector productivity.

\subsection{Estimation Techniques}

This study employs ordinary least square (OLS) multiple regression for the estimation.

We employ the Augmented Dickey Fuller (ADF) method of unit root to test the stationarity of the data. The data used for this study were time series secondary data which cover the period of 1986-2010. All the variables are sourced from the central Bank of Nigeria statistical bulletin which are downloaded from their website as well as Nigeria federal office of statistic (FOS). They include data on exchange rate which is expressed in terms of naira to dollar Inflation rate, real interest rate and Manufacturing direct investment.

\subsection{Data Analysis and Presentation of Result}

\subsubsection{Unit Root Test Result}

\begin{tabular}{|l|l|l|l|}
\hline Variance & Intercept & T-Statistic & Probability \\
\hline MDGP & $1^{\text {st }}$ difference & -4.998064 & 0.0015 \\
\hline EXR & $1^{\text {st }}$ difference & -4.717870 & 0.0012 \\
\hline INF & $1^{\text {st }}$ Difference & -4.873397 & 0.0008 \\
\hline
\end{tabular}




\begin{tabular}{|l|l|l|l|}
\hline DUM & $1^{\text {st }}$ Difference & -5.916080 & 0.0001 \\
\hline DUM & $1^{\text {st }}$ Difference & -5.338539 & 0.0003 \\
\hline MFDI & $1^{\text {st }}$ Difference & -4.778764 & 0.0004 \\
\hline RIR & $1^{\text {st }}$ Difference & -7.441891 & 0.0000 \\
\hline
\end{tabular}

The table above shows the results of the Augmented Dickey-Fuller (ADF) unit root test. At their $1^{\text {st }}$ difference forms, the ADF test suggests that the manufacturing gross domestic product, Exchange rate, inflation, real interest rate, Manufacturing direct investment and the dummy variable are stationary, at 5\%. Owing to the level of integration of our variables at first difference, we run the conventional Johansen cointegration test.

Trace test indicates 7 cointegrating equation (s) at the 0.05 level.

* denotes rejection of the hypothesis at the 0.05 level

***MacKinnon-Haug-Michelis (1999) p-values

Max-eigenvalue test indicates 4 cointegrating equation (s) at the 0.05 level

* denotes rejection of the hypothesis at the 0.05 level.

After conducting the Johansen cointegration test on the variables included, we find evidence of long run relationship between our variables.

\subsection{Ordinary Least Square and Sensitivity Test.}

The table below shows the summary of the Ordinary Least Squares method of linear regression obtained by using E-views.

Table : OLS Estimation Result

\begin{tabular}{|l|r|r|r|r|}
\hline Variable & \multicolumn{1}{|l|}{ Coefficient } & Standard Error & T-Statistic & \multicolumn{1}{l|}{ Probability } \\
\hline C & 23228.12 & 17954.83 & 1.293697 & 0.2141 \\
\hline EXR & -212.7368 & 171.0410 & -1.243777 & 0.0000 \\
\hline INF & 211.2746 & 293.8868 & 0.718898 & 0.4826 \\
\hline DUM & 13026.04 & 12088.85 & 1.077526 & 0.2972 \\
\hline DUM & 3458.318 & 13003.22 & 0.265959 & 0.7937 \\
\hline MDFI & 0.834929 & 0.042524 & 19.63412 & 0.0000 \\
\hline RIR & -207.5004 & 295.6410 & -0.701866 & 0.4928 \\
\hline
\end{tabular}

$\mathrm{R}^{2}=0.994837$

Adjusted R ${ }^{2}=0.992578$

Durbin Watson Stat $=2.000109$

Probability (f-statistic) $=0.000000$

The Durbin Watson shows there's no auto correlation as it rises from 1.63449 in test two to 2.000109 in test three. Before arriving at the final conclusion of the analysis, three tests were carried out with different variables in attempt to test how closely related each variable is to manufacturing gross domestic output. The first test was carried out with variables Exchange rate, Inflation and one dummy variable. The result derived from this analysis was relatively low as compared to the second test.

$\mathrm{R}^{2}$ was 0.797083 ; Adjusted $\mathrm{R}^{2}$ was 0.781876 with a very low Durbin Watson of 0.384634 .

\subsubsection{Second Test}

On realizing the low values derived in the first test, we went further to add more variables such as manufacturing direct investment and also another dummy variable to differentiate the different exchange rate regimes in the period of SAP and post-SAP period. On running the regression analysis, we were able to derive a higher value of $\mathrm{R}^{2} 0.994698$ and the adjusted $\mathrm{R}^{2}$ as 0.993303 with Durbin Watson as 1.633449 . This shows that manufacturing direct investment has a high impact on the result of manufacturing gross domestic product. The Durbin Watson showed positive serial correlation, which wasn't satisfactory enough. Consequently, we ran a third test.

\subsubsection{Third Test}

Real interest rate was then added to the model. After running the data on E-Views, we were able to come up with the following analysis. When comparing the $\mathrm{R}^{2}$ of test two to test three, $\mathrm{R}^{2}$ for test three is relatively higher than that of test two ( 0.994698 and 0.994837 respectively) meaning that real interest rate is also an important contributor to the outcome of manufacturing gross domestic product, but the adjusted $\mathrm{R}^{2}$ of test three is relatively low compared to test two (0.992578 and 0.93303 respectively), having adjusted for the error(s) that may be inherent in $\mathrm{R}^{2}$. 

207.5004 RIR

\section{Interpretation of Analysis}

From the above illustrated analysis, the coefficient of exchange rate is observed to be negative. This suggests that there is an inherent inverse relationship between exchange rate and manufacturing gross domestic product. This is akin to a priori expectation; if exchange rate increases by lunit, it is clear that manufacturing domestic product would have a reduction of 212.736 units. Also, our empirical evidence suggests that as the rate of inflation increases over the years by 1 unit, manufacturing gross domestic would also increase by 211.2746 units because theoretically there is a direct relationship between inflation and manufacturing gross domestic product. The real interest rate is expected to fall as manufacturing gross domestic product increases. Our empirical study shows that as real interest rate increases by 1 unit, the manufacturing gross domestic product reduces by 207.5004 units. Manufacturing foreign direct investment and manufacturing gross domestic production exhibit a positive relationship. It shows that 1 unit increase in manufacturing foreign direct investment would lead to 0.834929 increases in manufacturing gross domestic product. The dummy variables showed a direct relationship with manufacturing gross domestic product, and 1 unit increase in the dummy variables (both for SAP and Post-SAP periods) would lead to 13026.04 and 3458.318 increase in manufacturing gross domestic product respectively.

The $\mathrm{R}^{2}$ was 0.994837 i.e. about $99.48 \%$ variation in MGDP is explained by all the variables (INF, EXR, MFDI, RIR and DUM), while the remaining variation is captured by the error term; therefore, we conclude that our estimated model is of good fit and reliable for making policy. The p-value for the f-statistic is 0.0000 which is less than 0.05 . At $5 \%$ significance level; we reject the null hypothesis and conclude that our estimated model is statistically significant.

Heteroskedasticity WHITE test was done to test for multicollinearity. The observation from the result of the multicollinearity test is that the cantered VIF have values lower than 5, meaning that there is no severe multicollinearity.

\section{Discussion of Findings}

It can be inferred from the empirical result that the dummy which explained the appreciation and depreciation of the exchange rate shows that the exchange rate depreciation opted by the Government as part of its exchange rate management policy has not contributed significantly to the growth of manufacturing product as explained by the dummy data. The implication is that the exchange rate appreciation should be pursued instead of depreciation. It could also be ascertained from the estimated regression line that there is a positive relationship between the manufacturing gross domestic product and inflation.

\section{Summary, Conclusion and Recommendation}

Following from literature, it was found in Vietnam that exchange rate depreciation can promote output while in America it was discovered that appreciation of dollar would tend to contract manufacturing output. From this study, it was found that in Nigeria exchange rate appreciation does have a significant relationship with domestic output. This is in contrast to the theoretical expectation that depreciation will promote manufacturing export, encouragement of local use of input and growth in the manufacturing sector. On the basis of these findings, it can be concluded that the exchange rate management policy which presently tends towards exchange rate depreciation has not contributed significantly to the growth of the manufacturing sector in Nigeria. The result of this study suggests that the exchange rate appreciation is what we need to pursue instead of exchange rate depreciation. This may be due to the fact that the machineries and equipments as well as much of the raw materials, being used in the Nigerian manufacturing sector are imported to the country.

The following recommendation is made towards exchange rate management and growth of manufacturing sector productivity. Since manufacturing sector depends much on foreign inputs, and for the importation of these foreign inputs not be continuous, efforts should be geared towards improving the level of technology, increasing agricultural production, and developing local raw materials in the country. In addition, the government should ensure stable electricity, good roads, water, telecommunication etc. And more importantly as regards this study, the exchange rate appreciation is what the Government should intensify efforts to achieve in Nigeria.

\section{References}

[1] Central Bank of Nigeria (CBN) Annual Report and Statement of Account (various editions)

[2] Manufacturers association of Nigeria MAN. Newsletter Publication (various issues).

[3] E. Ubok-Udom, Currency depreciation and domestic output growth in Nigeria, the Nigeria Journal of economics and social studies. 1999. 
[4] O.J.K. Ogundele, Determinants of Entrepreneurial Emergence Behaviour and Performance in Nigeria. Unpublished Doctoral Thesis. Faculty of Business Administration, University of Lagos. (2000)

[5] Malik, Teal F, Baptists, The Performance of Nigerian Manufacturing Firms. Report of the Nigerian Manufacturing Survey. Centre for the study of African Economics University of Oxford, U.K. (2006)

[6] World Development Report. The World Bank Washington Dc. Various Editions

[7] C.M. Anyanwu, Productivity in the Nigerian Manufacturing Industry. Research Dept. CBN available at www.cenbank.org/oui/publication (2006)

\section{$\underline{\text { APPENDIX }}$}

Presentation of Data

\begin{tabular}{|l|r|l|r|r|r|r|r|}
\hline Year & MDGP $(\mathrm{Y})$ & $\begin{array}{l}\text { EXR } \\
(\mathrm{X} 1)\end{array}$ & $\begin{array}{l}\text { INF } \\
(\mathrm{X} 2)\end{array}$ & $\begin{array}{l}\text { DUM1 } \\
(\mathrm{X} 3)\end{array}$ & $\begin{array}{l}\text { DUM2 } \\
(\mathrm{X} 4)\end{array}$ & $\begin{array}{l}\text { MFDI } \\
(\mathrm{X} 5)\end{array}$ & $\begin{array}{l}\text { RIR } \\
(\mathrm{X} 6)\end{array}$ \\
\hline 1986 & 6591.1 & 2.0206 & 5.4 & 1 & 1 & 6591.1 & 11.63228745 \\
\hline 1987 & 7468.5 & 4.0179 & 10.2 & 0 & 1 & 7468.5 & -24.06710072 \\
\hline 1988 & 11017.8 & 4.5367 & 38.3 & 1 & 0 & 11017.8 & -3.920856122 \\
\hline 1989 & 12475.5 & 7.3916 & 40.9 & 0 & 1 & 12475.5 & -16.57844108 \\
\hline 1990 & 14702.4 & 8.0378 & 7.5 & 1 & 0 & 14702.4 & 16.92732414 \\
\hline 1991 & 19356 & 9.9095 & 13 & 0 & 1 & 19356 & -0.110733083 \\
\hline 1992 & 27004 & 17.2984 & 44.5 & 1 & 0 & 27004 & -32.05731051 \\
\hline 1993 & 38987.1 & 22.0511 & 57.2 & 0 & 1 & 38987.1 & -13.74923058 \\
\hline 1994 & 62897.7 & 21.8861 & 57 & 1 & 0 & 62897.7 & -5.702380375 \\
\hline 1995 & 105289.6 & 21.8861 & 72.8 & 0 & 1 & 105289.6 & -22.91094097 \\
\hline 1996 & 132897.1 & 21.8861 & 29.3 & 1 & 0 & 132897.1 & -12.46367043 \\
\hline 1997 & 144107 & 21.8861 & 8.5 & 0 & 1 & 144107 & 16.2132807 \\
\hline 1998 & 141496 & 21.8861 & 10 & 1 & 0 & 141496 & 25.1300099 \\
\hline 1999 & 150946.5 & 92.6934 & 6.6 & 0 & 1 & 150946.5 & 7.127715426 \\
\hline 2000 & 168037 & 102.1052 & 6.9 & 1 & 0 & 168037 & -12.22751594 \\
\hline 2001 & 199079.3 & 111.9433 & 18.9 & 0 & 1 & 199079.3 & 11.46917384 \\
\hline 2002 & 236825.5 & 120.9702 & 12.9 & 1 & 0 & 236825.5 & -5.098434484 \\
\hline 2003 & 287739.4 & 129.3565 & 14 & 0 & 1 & 287739.4 & 8.560264468 \\
\hline 2004 & 349316.3 & 133.5004 & 15 & 1 & 0 & 349316.3 & -1.28126554 \\
\hline 2005 & 412706.6 & 132.147 & 17.9 & 0 & 1 & 412706.6 & -1.513291533 \\
\hline 2006 & 454628.7 & 128.7 & 8.2 & 1 & 0 & 476748.7 & -2.223439768 \\
\hline 2007 & 487536.7 & 125.8 & 5.4 & 0 & 1 & 526845 & 11.57313977 \\
\hline 2008 & 545368.7 & 118.5 & 11.6 & 1 & 0 & 566759.6 & 4.067881778 \\
\hline 2009 & 575848.2 & 148.9 & 11.5 & 0 & 1 & 685937.3 & 23.88698732 \\
\hline 2010 & 620012 & 150.3 & 13.7 & 1 & 0 & 720504.6 & 6.648385839 \\
\hline & & & & & & & \\
\hline
\end{tabular}

Unrestricted Test Equation:

Dependent Variable: Y

Method: Least Squares

Date: 05/28/12 Time: 10:17

Sample: 19862009

Included observations: 24

\begin{tabular}{crrrr}
\hline \hline Variable & Coefficient & Std. Error & t-Statistic & Prob. \\
\hline \hline C & 21780.13 & 15446.98 & 1.409993 & 0.1766 \\
X1 & 207.5573 & 126.7094 & 1.638058 & 0.0000 \\
X2 & -214.7538 & 243.8969 & -0.880511 & 0.3909 \\
X3 & -16109.02 & 11314.87 & -1.423704 & 0.1726 \\
X4 & 3748.178 & 12776.64 & 0.293362 & 0.7728 \\
X5 & 0.860158 & 0.034438 & 24.97716 & 0.0000 \\
X6 & -252.8585 & 290.0145 & -0.871882 & 0.3954 \\
\hline \hline & 0.994770 & Mean dependent var & 191346.8 \\
R-squared & 0.992924 & S.D. dependent var & 185715.1 \\
Adjusted R-squared & 15622.24 & Akaike info criterion & 22.38927 \\
S.E. of regression & $4.15 E+09$ & Schwarz criterion & 22.73287 \\
Sum squared resid & \multicolumn{4}{l}{}
\end{tabular}


Log likelihood
F-statistic
Prob(F-statistic)
-261.6713 Hannan-Quinn criter.

538.8980 Durbin-Watson stat

0.000000
22.48043

1.827039

At $0.05 \%$ probability is not significant implying that the structural break between SAP and post-SAP period had no significant effects on the result.

Ordinary Least Square Analysis On E-Views

Dependent Variable: Y

Method: Least Squares

Date: 05/22/12 Time: 23:35

Sample(adjusted): 19872010

Included observations: 24

\begin{tabular}{crcrr}
\hline \hline Variable & Coefficient & Std. Error & t-Statistic & Prob. \\
\hline C & 23228.12 & 17954.83 & 1.293697 & 0.2141 \\
X1 & -212.7368 & 171.0410 & -1.243777 & 0.0000 \\
X2 & 211.2746 & 293.8868 & 0.718898 & 0.4826 \\
X3 & 13026.04 & 12088.85 & 1.077526 & 0.2972 \\
X4 & 3458.318 & 13003.22 & 0.265959 & 0.7937 \\
X5 & 0.834929 & 0.042524 & 19.63412 & 0.0000 \\
X6 & -207.5004 & 295.6410 & -0.701866 & 0.4928 \\
& & & \\
R-squared & 0.994837 & Mean dependent var & & 216906.0 \\
Adjusted R-squared & 0.992578 & S.D. dependent var & & 200782.4 \\
S.E. of regression & 17297.69 & Akaike info criterion & & 22.61574 \\
Sum squared resid & $4.79 E+09$ & Schwarz criterion & & 23.00842 \\
Log likelihood & -263.3888 & F-statistic & 440.4097 \\
Durbin-Watson stat & 2.000109 & Prob(F-statistic) & & 0.000000 \\
\hline \hline
\end{tabular}

Sample (adjusted): 19882010

Included observations: 23 after adjustments

Trend assumption: Linear deterministic trend

Series: Y X1 X2 X3 X4 X5 X6

Lags interval (in first differences): 1 to 1

Unrestricted Cointegration Rank Test (Trace)

\begin{tabular}{ccccc}
\hline \hline $\begin{array}{c}\text { Hypothesized } \\
\text { No. of CE(s) }\end{array}$ & Eigenvalue & $\begin{array}{c}\text { Trace } \\
\text { Statistic }\end{array}$ & $\begin{array}{c}0.05 \\
\text { Critical Value }\end{array}$ & Prob.** \\
\hline \hline None $*$ & 0.993903 & 265.7761 & 125.6154 & 0.0000 \\
At most 1* & 0.842466 & 148.4774 & 95.75366 & 0.0000 \\
At most 2* & 0.801894 & 105.9709 & 69.81889 & 0.0000 \\
At most 3* & 0.728418 & 68.73493 & 47.85613 & 0.0002 \\
At most 4* & 0.569573 & 38.75465 & 29.79707 & 0.0036 \\
At most 5* & 0.430949 & 19.36618 & 15.49471 & 0.0124 \\
At most 6* & 0.242871 & 6.399107 & 3.841466 & 0.0114 \\
\hline \hline
\end{tabular}

Trace test indicates 7 cointegratingeqn(s) at the 0.05 level

* denotes rejection of the hypothesis at the 0.05 level

**MacKinnon-Haug-Michelis (1999) p-values

Unrestricted Cointegration Rank Test (Maximum Eigenvalue) 


\begin{tabular}{ccccc}
$\begin{array}{c}\text { Hypothesized } \\
\text { No. of CE(s) }\end{array}$ & Eigenvalue & $\begin{array}{c}\text { Max-Eigen } \\
\text { Statistic }\end{array}$ & $\begin{array}{c}0.05 \\
\text { Critical Value }\end{array}$ & Prob.** \\
\hline \hline None $*$ & 0.993903 & 117.2987 & 46.23142 & 0.0000 \\
At most $1 *$ & 0.842466 & 42.50655 & 40.07757 & 0.0261 \\
At most 2* & 0.801894 & 37.23595 & 33.87687 & 0.0191 \\
At most 3* & 0.728418 & 29.98027 & 27.58434 & 0.0241 \\
At most 4 & 0.569573 & 19.38847 & 21.13162 & 0.0861 \\
At most 5 & 0.430949 & 12.96707 & 14.26460 & 0.0793 \\
At most 6 & 0.242871 & 6.399107 & 3.841466 & 0.0114 \\
\hline \hline
\end{tabular}

Max-eigenvalue test indicates 4 cointegratingeqn(s) at the 0.05 level

* denotes rejection of the hypothesis at the 0.05 level.

After conducting the Johansen cointegration test on the variables included, we find evidence of long run relationship between our variables. The Max-eigenvalues test indicates the presence of a cointegration relationship at $5 \%$.

HETEROSKEDASITCITY TEST: WHITE

Heteroskedasticity Test: White

\begin{tabular}{llll}
\hline \hline F-statistic & 6.141283 & Prob. F(6,18) & 0.0012 \\
Obs*R-squared & 16.79546 & Prob. Chi-Square(6) & 0.0101 \\
Scaled explained SS & 13.30769 & Prob. Chi-Square(6) & 0.0384 \\
\hline \hline
\end{tabular}

Test Equation:

Dependent Variable: RESID^2

Method: Least Squares

Date: 05/25/12 Time: 10:47

Sample: 19862010

Included observations: 25

\begin{tabular}{crrrr}
\hline \hline \multicolumn{1}{c}{ Variable } & Coefficient & Std. Error & t-Statistic & Prob. \\
\hline \hline $\mathrm{C}$ & -4036075. & $2.17 \mathrm{E}+08$ & -0.018580 & 0.9854 \\
$\mathrm{X} 1^{\wedge} 2$ & -15960.69 & 11633.52 & -1.371958 & 0.0002 \\
$\mathrm{X}^{\wedge} 2$ & -7220.964 & 43347.96 & -0.166581 & 0.8696 \\
$\mathrm{X}^{\wedge} 2$ & 486007.1 & $1.74 \mathrm{E}+08$ & 0.002799 & 0.9978 \\
$\mathrm{X}^{\wedge} 2$ & 56698954 & $1.94 \mathrm{E}+08$ & 0.292585 & 0.7732 \\
$\mathrm{X}^{\wedge} 2$ & 0.002544 & 0.000578 & 4.398776 & 0.0003 \\
\multicolumn{1}{c}{$\mathrm{X6}^{\wedge} 2$} & 168069.8 & 213832.8 & 0.785987 & 0.4421 \\
\hline \hline & & & & \\
R-squared & 0.671818 & Mean dependent var & $2.01 \mathrm{E}+08$ \\
Adjusted R-squared & 0.562425 & S.D. dependent var & $3.59 \mathrm{E}+08$ \\
S.E. of regression & $2.37 \mathrm{E}+08$ & Akaike info criterion & 41.63921 \\
Sum squared resid & $1.01 \mathrm{E}+18$ & Schwarz criterion & 41.98049 \\
Log likelihood & -513.4901 & Hannan-Quinn criter. & 41.73386 \\
F-statistic & 6.141283 & Durbin-Watson stat & 2.038307 \\
Prob(F-statistic) & 0.001208 & & \\
\hline \hline
\end{tabular}

The result above shows the residual variance of the variables of the model is constant, meaning that there is homoscedasticity. 


\section{Multicollinearity Test}

Variance Inflation Factors

Date: 05/24/12 Time: 14:50

Sample: 19862010

Included observations: 24

\begin{tabular}{cccc}
\hline \hline Variable & $\begin{array}{c}\text { Coefficient } \\
\text { Variance }\end{array}$ & $\begin{array}{c}\text { Uncentered } \\
\text { VIF }\end{array}$ & $\begin{array}{c}\text { Centered } \\
\text { VIF }\end{array}$ \\
\hline \hline C & $3.22 \mathrm{E}+08$ & 13.48500 & NA \\
X1 & 29254.72 & 10.45074 & 4.058081 \\
X2 & 86369.42 & 3.535835 & 1.740592 \\
X3 & $1.46 \mathrm{E}+08$ & 5.891774 & 1.211451 \\
X4 & $1.69 \mathrm{E}+08$ & 7.111480 & 1.168343 \\
X5 & 0.001808 & 8.306196 & 3.928298 \\
X6 & 87404.13 & 1.493651 & 1.489928 \\
\hline \hline
\end{tabular}

How Forecast Test

Equation: UNTITLED

Specification: Y C X1 X2 X3 X4 X5 X6

Test predictions for observations from 2010 to 2010

\begin{tabular}{|c|c|c|c|}
\hline & Value & Df & Probability \\
\hline t-statistic & 1.895992 & 17 & 0.0751 \\
\hline F-statistic & 3.594787 & $(1,17)$ & 0.0751 \\
\hline Likelihood ratio & 4.795616 & 1 & 0.0285 \\
\hline \multicolumn{4}{|l|}{ F-test summary: } \\
\hline & Sum of Sq. & Df & Mean Squares \\
\hline Test SSR & $8.77 \mathrm{E}+08$ & 1 & $8.77 \mathrm{E}+08$ \\
\hline Restricted SSR & $5.03 \mathrm{E}+09$ & 18 & $2.79 \mathrm{E}+08$ \\
\hline Unrestricted SSR & $4.15 \mathrm{E}+09$ & 17 & $2.44 \mathrm{E}+08$ \\
\hline Unrestricted SSR & $4.15 \mathrm{E}+09$ & 17 & $2.44 \mathrm{E}+08$ \\
\hline \multicolumn{4}{|l|}{ LR test summary: } \\
\hline & Value & Df & \\
\hline Restricted LogL & -274.4618 & 18 & \\
\hline Unrestricted LogL & -272.0640 & 17 & \\
\hline
\end{tabular}

Unrestricted log likelihood adjusts test equation results to account for observations in forecast sample 